\title{
Rhodococcus jialingiae sp. nov., an actinobacterium isolated from sludge of a carbendazim wastewater treatment facility
}

\author{
Zhichun Wang, ${ }^{1} \dagger$ Jingliang $\mathrm{Xu},{ }^{1} \dagger \mathrm{Yan} \mathrm{Li}^{2}{ }^{2}$ Kun Wang, ${ }^{1}$ Yangyang Wang, ${ }^{1}$ \\ Oing Hong, ${ }^{1}$ Wen-Jun $\mathrm{Li}^{2,3}$ and Shun-Peng $\mathrm{Li}^{1}$
}

\author{
Correspondence \\ Shun-Peng Li \\ Isp@njau.edu.cn \\ Wen-Jun Li \\ wjli@ynu.edu.cn
}

\author{
${ }^{1}$ Key Laboratory for Microbiological Engineering of Agricultural Environment of Ministry of \\ Agriculture, Nanjing Agricultural University, Nanjing 210095, PR China
${ }^{2}$ The Key Laboratory for Microbial Resources of Ministry of Education, PR China, and Laboratory for Conservation and Utilization of Bio-Resources, Yunnan Institute of Microbiology, Yunnan University, Kunming 650091, PR China
${ }^{3}$ Guangdong Key Laboratory of Marine Materia Medica, South China Sea Institute of Oceanology, Chinese Academy of Sciences, Guangzhou 510301, PR China

The genus Rhodococcus was described by Zopf (1891), and the description of the genus has subsequently been emended as the classification of the rhodococci has been greatly improved by the application of a polyphasic approach (Goodfellow et al., 1998, 1999). Members of the genus show broad catabolic diversity and enzymic capabilities of environmental and biotechnological importance (Warhurst \& Fewson, 1994; Bell et al., 1998). In the present study, an efficient carbendazim-degrading actinobacterium, strain djl-6-2 $2^{\mathrm{T}}$, was isolated from sludge of a carbendazim wastewater treatment facility in Jiangsu province, China. Carbendazim, one of the most widely used fungicides, can harm the liver and endocrine system and has mutagenic and teratogenic effects on animals even at low concentrations (Mazellier et al., 2003). Some strains of Rhodococcus capable of degrading carbendazim have been reported, but only a few of these can degrade

†These authors contributed equally to this work.

The GenBank/EMBL/DDBJ accession number for the 16S rRNA gene sequence of strain djl-6-2 ${ }^{\top}$ is DQ185597.

A comparison of fatty acid profiles of strain dj $-6-2^{\top}$ and related strains and an extended neighbour-joining tree are available as supplementary material with the online version of this paper. carbendazim completely (Holtman \& Kobayashi, 1997; Zhang et al., 2005a; Xu et al., 2006a, b, 2007).

Strain djl-6-2 ${ }^{\mathrm{T}}$ grew well on Luria-Bertani (LB) medium or minimal medium with carbendazim as sole carbon and energy source under aerobic conditions at $30{ }^{\circ} \mathrm{C}(\mathrm{Xu}$ et al., $2006 \mathrm{~b})$ and was maintained as glycerol stocks (20\%, v/v) at $-70{ }^{\circ} \mathrm{C}$. For studying cell morphology, the strain was incubated on LB medium at $30{ }^{\circ} \mathrm{C}$. Morphology was observed by light microscopy (BH-2; Olympus) and transmission electron microscopy (H-7650; Hitachi). The Gram reaction was determined according to the procedure of Buck (1982). Acid-fast staining was performed as described by Ebersole (1992). Strain djl-6-2 ${ }^{\mathrm{T}}$ was Grampositive, non-spore-forming, non-motile and non-acidfast, showed elementary branching, had a rod-coccus growth cycle and formed opaque, slightly pink, moist, smooth and domed colonies with regular edges on LB agar.

Physiological tests, such as growth at different temperatures, $\mathrm{pH}$ and $\mathrm{NaCl}$ concentrations, were examined by growing the strain on LB medium using the methods of Gordon (1966, 1967). Carbon-source utilization by djl-6$2^{\mathrm{T}}$ and related type strains was investigated by using API $50 \mathrm{CH}$ strips (bioMérieux), while some substrates were 
tested as described by Shirling \& Gottlieb (1966). Urease production was determined as described by Cowan \& Steel (1965), nitrate reduction was determined as described by Lányí (1987), hydrolysis of starch and gelatin was determined as described by Smibert \& Krieg (1994) and the Voges-Proskauer and methyl red tests and the production of $\mathrm{H}_{2} \mathrm{~S}$ and indole were tested as described by Goodfellow (1986). Catalase activity was determined by bubble formation after the addition of a drop of $3 \% \mathrm{H}_{2} \mathrm{O}_{2}$. Oxidase activity was determined from the oxidation of tetramethyl-p-phenylenediamine. Detailed physiological and biochemical results for strain djl-6-2 $2^{\mathrm{T}}$ are given in Table 1 and in the species description.

Amino acids and sugars of whole-cell hydrolysates were determined by using TLC as described by Staneck \& Roberts (1974). Menaquinones were extracted using the methods of Minnikin et al. (1984) and separated by HPLC (Kroppenstedt, 1982). The presence of mycolic acids was analysed by TLC (Minnikin et al., 1980). Analysis of the cellular fatty acid composition followed the instructions of the Microbial Identification System (MIDI) (Sasser, 1990).
Phospholipids were extracted and identified using published procedures (Collins \& Jones, 1980; Minnikin et al., 1979).

Extraction of genomic DNA and amplification of the 16S rRNA gene were done as described by Xu et al. (2006b). The $16 \mathrm{~S}$ rRNA gene sequence of strain djl-6-2 $2^{\mathrm{T}}$ and type strains within the genus Rhodococcus were selected for the calculation of pairwise sequence similarity using a global alignment algorithm, which was implemented at the EzTaxon server 2.1 (http://www.eztaxon.org/; Chun et al., 2007). Phylogenetic analysis was performed using MEGA version 2.1 (Kumar et al., 2001). Evolutionary distances and the $K_{\text {nuc }}$ value (Kimura, 1983) were calculated and clustering was performed with the neighbour-joining method (Saitou \& Nei, 1987). The topology of the phylogenetic tree was evaluated by the bootstrap resampling method of Felsenstein (1985) with 1000 replicates. DNADNA hybridization was performed by the method of De Ley et al. (1970). The G $+C$ content of the genomic DNA was determined by thermal denaturation (Marmur \& Doty, 1962) with DNA from Escherichia coli JM109 as a standard.

Table 1. Phenotypic characteristics that differentiate strain djl-6-2 ${ }^{\top}$ from closely related type strains

Strains: 1, djl-6-2 ${ }^{\mathrm{T}} ; 2$, R. qingshengii djl-6 $6^{\mathrm{T}} ; 3$, R. baikonurensis DSM 44587 ${ }^{\mathrm{T}} ; 4$, R. erythropolis DSM 43066 ${ }^{\mathrm{T}} ; 5$, R. globerulus DSM $43954^{\mathrm{T}}$. Some data for reference type strains were taken from previous studies (Yoon et al., 2000; Li et al., 2004; Zhang et al., 2002, 2005b; Xu et al., 2007); data for strain djl-6-2 $2^{\mathrm{T}}$ are from the present study. +, Positive; w, weakly positive; - , negative; ND, no data available.

\begin{tabular}{|c|c|c|c|c|c|}
\hline Characteristic & 1 & 2 & 3 & 4 & 5 \\
\hline Maximum $\mathrm{NaCl}$ concentration $(\%, \mathrm{w} / \mathrm{v})$ & 7 & 5 & 6 & 5 & 3 \\
\hline \multicolumn{6}{|l|}{ Utilization as sole carbon source of: } \\
\hline Arabitol & + & - & - & + & + \\
\hline L-Asparagine & - & - & + & $\mathrm{w}$ & + \\
\hline Catechol & + & + & - & - & - \\
\hline D-Fructose & + & - & + & + & + \\
\hline Inulin & - & - & - & - & + \\
\hline myo-Inositol & + & - & - & + & - \\
\hline L-Lactic acid & - & - & + & + & + \\
\hline D-Sorbitol & - & - & + & + & + \\
\hline Sucrose & - & $\mathrm{W}$ & - & + & + \\
\hline Trehalose & - & - & - & + & + \\
\hline Xylitol & - & - & - & - & + \\
\hline D-Xylose & - & - & - & - & + \\
\hline Phospholipids ${ }^{*}$ & DPG, PE, PG, PI, PIM & PG, PI, PME & CL, PE, PI, PIM & $\mathrm{ND}$ & ND \\
\hline DNA G $+C$ content $(\mathrm{mol} \%)$ & 60.1 & 59.1 & 55.5 & $\mathrm{ND}$ & $\mathrm{ND}$ \\
\hline
\end{tabular}

${ }^{*} \mathrm{CL}$, Cardiolipin; DPG, diphosphatidylglycerol; PE, phosphatidylethanolamine; PG, phosphatidylglycerol; PI, phosphatidylinositol; PIM, phosphatidylinositol mannoside; PME, phosphatidylmethylethanolamine. 
Strain djl-6-2 $2^{\mathrm{T}}$ contained meso-diaminopimelic acid as the diamino acid in the cell wall. Whole-cell sugars were ribose, arabinose and galactose. The predominant menaquinone was MK- $8\left(\mathrm{H}_{2}\right)$. The phospholipids were diphosphatidylglycerol, phosphatidylglycerol, phosphatidylinositol mannoside, phosphatidylethanolamine and phosphatidylinositol. The major fatty acids were $\mathrm{C}_{16: 0}(36.8 \%)$, $\mathrm{C}_{18: 1} \omega 9 c \quad(27.3 \%), \mathrm{C}_{14: 0} \quad(10.0 \%), \mathrm{C}_{18: 0} \quad(4.9 \%), 10-$ methyl $\mathrm{C}_{18: 0}$ (tuberculostearic acid) (3.7\%), $\mathrm{C}_{17: 1} \omega 8 \mathrm{c}$ $(1.4 \%)$ and $\mathrm{C}_{15: 0}(1.3 \%)$ (only components that represent $\geqslant 1 \%$ of the total are reported). Mycolic acids were present. The $\mathrm{G}+\mathrm{C}$ content of strain djl-6-2 ${ }^{\mathrm{T}}$ was $60.1 \mathrm{~mol} \%$. The results of the chemotaxonomic and morphological tests were consistent with its classification in the genus Rhodococcus.

Phylogenetic analysis based on 16S rRNA gene sequences showed that strain djl-6-2 ${ }^{\mathrm{T}}$ was closely related to Rhodococcus qingshengii djl- $6^{\mathrm{T}} \quad(99.80 \%$ similarity), Rhodococcus baikonurensis GTC $1041^{\mathrm{T}} \quad(99.78 \%)$, Rhodococcus erythropolis DSM $43066^{\mathrm{T}}(99.12 \%)$ and Rhodococcus globerulus DSM $43954^{\mathrm{T}}$ (98.75\%), but showed less than $97 \%$ similarity to other members of the genus Rhodococcus (Fig. 1). However, the levels of DNA-DNA relatedness of strain djl-6- $2^{\mathrm{T}}$ to $R$. qingshengii djl- $6^{\mathrm{T}}, R$. baikonurensis DSM $44587^{\mathrm{T}}$, R. erythropolis DSM $43066^{\mathrm{T}}$ and R. globerulus DSM $43954^{\mathrm{T}}$ were $27.7,19.3,18.6$ and $10.6 \%$, respectively. These data are consistent with the conclusion drawn by Yassin (2005) and Ghosh et al. (2006) that representatives of Rhodococcus species with 16S rRNA gene sequence similarity greater than $98 \%$ share whole genomic relatedness values well below the $70 \%$ threshold value for the delineation of genomic species (Stackebrandt \& Goebel, 1994).

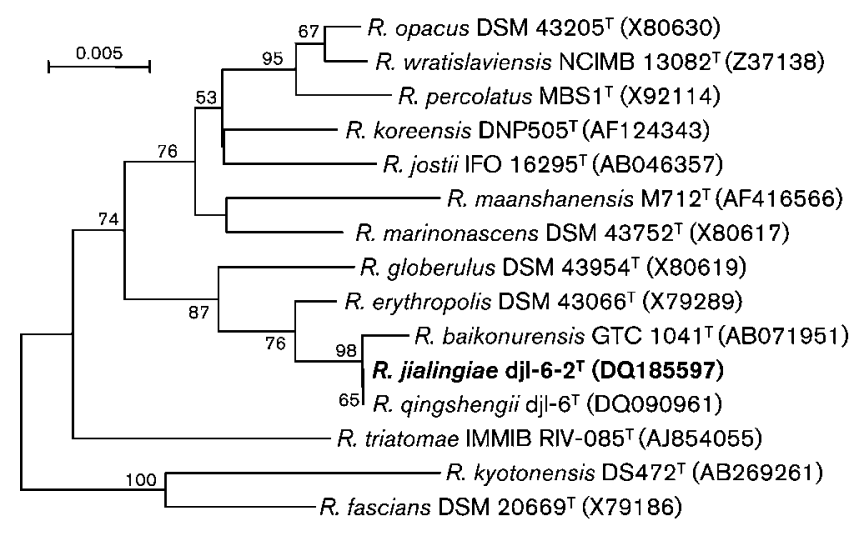

Fig. 1. Neighbour-joining tree showing the phylogenetic relationship between strain djl-6-2 ${ }^{\top}$ and its closest relatives, based on $16 \mathrm{~S}$ rRNA gene sequences. Bootstrap values (expressed as percentages of 1000 replications) greater than $50 \%$ are shown at branch points. Bar, 0.005 substitutions per site. Accession numbers are given in parentheses. An extended version of this tree is available as Supplementary Fig. S1.
Based on the phenotypic (Table 1 and Supplementary Table S1, available in IJSEM Online) and phylogenetic (Fig. 1 and Supplementary Fig. S1) evidence presented, strain djl-6-2 $2^{\mathrm{T}}$ should be assigned to the genus Rhodococcus as the type strain of a novel species, for which the name Rhodococcus jialingiae sp. nov. is proposed.

\section{Description of Rhodococcus jialingiae sp. nov.}

Rhodococcus jialingiae (jia.lin'gi.ae. N.L. fem. gen. n. jialingiae of Jia-Ling, to honour Jia-Ling Wang, a respected Chinese microbiologist, for her enormous contributions to the development of environmental microbiology in China).

Gram-stain-positive, aerobic, non-motile, non-sporeforming, non-acid-fast bacterium, showing elementary branching and a rod-coccus life cycle. Colonies on LB plates are opaque, slightly pink, moist, smooth and convex with regular edges. Growth occurs at $4-35^{\circ} \mathrm{C}$ and $\mathrm{pH} 4.0$ 9.0. $\mathrm{NaCl}$ is tolerated at up to $7 \%$. Negative for oxidase, production of $\mathrm{H}_{2} \mathrm{~S}$ and indole, gelatin liquefaction, starch hydrolysis, nitrate reduction and the methyl red test, while positive for catalase, the Voges-Proskauer test and urease production. Utilizes D-arabitol, benomyl, carbendazim, catechol, aesculin ferric citrate, D-fructose, D-mannitol and myo-inositol as sole carbon sources, but inulin, D-mannose, D-sorbitol, sucrose, trehalose and D-xylose are not utilized. The diagnostic amino acid in the peptidoglycan is mesodiaminopimelic acid, and ribose, arabinose and galactose are dominant in whole-cell hydrolysates. Phospholipids are diphosphatidylglycerol, phosphatidylglycerol, phosphatidylinositol mannoside, phosphatidylethanolamine and phosphatidylinositol. The predominant menaquinone is MK- $8\left(\mathrm{H}_{2}\right)$. Mycolic acids are present. The major fatty acids $(\geqslant 10 \%)$ are $\mathrm{C}_{16: 0}, \mathrm{C}_{18: 1} \omega 9 c$ and $\mathrm{C}_{14: 0}$. The DNA G+C content of the type strain is $60.1 \mathrm{~mol} \%$.

The type strain, djl-6-2 $2^{\mathrm{T}}\left(=\mathrm{DSM} 45257^{\mathrm{T}}=\right.$ CCTCC AB $208292^{\mathrm{T}}$ ), was isolated from sludge of a carbendazim wastewater treatment facility in Jiangsu province, China.

\section{Acknowledgements}

This research was supported by the National Technology Platform Program of China (no. 2005DKA21201-2). W.-J. L. was supported by the Program for New Century Excellent Talent in University (NCET).

\section{References}

Bell, K. S., Philp, J., Aw, D. \& Christofi, N. (1998). The genus Rhodococcus. J Appl Microbiol 85, 195-210.

Buck, J. D. (1982). Nonstaining (KOH) method for determination of gram reactions of marine bacteria. Appl Environ Microbiol 44, 992-993.

Chun, J., Lee, J. H., Jung, Y., Kim, M., Kim, S., Kim, B. K. \& Lim, Y. W. (2007). EzTaxon: a web-based tool for the identification of prokaryotes based on $16 \mathrm{~S}$ ribosomal RNA gene sequences. Int J Syst Evol Microbiol 57, 2259-2261.

Collins, M. D. \& Jones, D. (1980). Lipids in the classification and identification of coryneform bacteria containing peptidoglycans based on 2,4-diaminobutyric acid. J Appl Bacteriol 48, 459-470. 
Cowan, S. T. \& Steel, K. J. (1965). Manual for the Identification of Medical Bacteria. London: Cambridge University Press.

De Ley, J., Cattoir, H. \& Reynaerts, A. (1970). The quantitative measurement of DNA hybridization from renaturation rates. Eur $J$ Biochem 12, 133-142.

Ebersole, L. L. (1992). Acid-fast stain procedures. In Clinical Microbiology Procedures Handbook, pp. 3.5.1-3.5.11. Edited by H. D. Isenberg. Washington, DC: American Society for Microbiology.

Felsenstein, J. (1985). Confidence limits on phylogenies: an approach using the bootstrap. Evolution 39, 783-791.

Ghosh, A., Paul, D., Prakash, D., Mayilraj, S. \& Jain, R. K. (2006). Rhodococcus imtechensis sp. nov., a nitrophenol-degrading actinomycete. Int J Syst Evol Microbiol 56, 1965-1969.

Goodfellow, M. (1986). Genus Rhodococcus Zopf 1891, 28 ${ }^{\mathrm{AL}}$. In Bergey's Manual of Systematic Bacteriology, vol. 2, pp. 1472-1481. Edited by P. H. A. Sneath, N. S. Mair, M. E. Sharpe \& J. G. Holt. Baltimore: Williams \& Wilkins.

Goodfellow, M., Alderson, G. \& Chun, J. (1998). Rhodococcal systematics: problems and developments. Antonie van Leeuwenhoek 74, 3-20.

Goodfellow, M., Isik, K. \& Yates, E. (1999). Actinomycete systematics: an unfinished synthesis. Nova Acta Leopold 312, 47-82.

Gordon, R. E. (1966). Some criteria for the recognition of Nocardia madurae (Vincent) Blanchard. J Gen Microbiol 45, 355-364.

Gordon, R. E. (1967). The taxonomy of soil bacteria. In The Ecology of Soil Bacteria, pp. 293-321. Edited by T. R. G. Gray \& B. Parkinson. Liverpool: Liverpool University Press.

Holtman, M. A. \& Kobayashi, D. Y. (1997). Identification of Rhodococcus erythropolis isolates capable of degrading the fungicide carbendazim. Appl Microbiol Biotechnol 47, 578-582.

Kimura, M. (1983). The Neutral Theory of Molecular Evolution. Cambridge: Cambridge University Press.

Kroppenstedt, R. M. (1982). Separation of bacterial menaquinones by HPLC using reverse phase (RP18) and a silver loaded ion exchanger as stationary phases. J Liq Chromatogr 5, 2359-2367.

Kumar, S., Tamura, K., Jakobsen, I. B. \& Nei, M. (2001). MEGA2: molecular evolutionary genetics analysis software. Bioinformatics 17, $1244-1245$.

Lányí, B. (1987). Classical and rapid identification methods for medically important bacteria. Methods Microbiol 19, 1-67.

Li, Y., Kawamura, Y., Fujiwara, N., Naka, T., Liu, H. S., Huang, X. X., Kobayashi, K. \& Ezaki, T. (2004). Rothia aeria sp. nov., Rhodococcus baikonurensis sp. nov. and Arthrobacter russicus sp. nov., isolated from air in the Russian space laboratory Mir. Int J Syst Evol Microbiol 54, 827-835.

Marmur, J. \& Doty, P. (1962). Determination of the base composition of deoxyribonucleic acid from its thermal denaturation temperature. J Mol Biol 5, 109-118.

Mazellier, P., Leroy, É., De Laat, J. \& Legube, B. (2003). Degradation of carbendazim by $\mathrm{UV} / \mathrm{H}_{2} \mathrm{O}_{2}$ investigated by kinetic modelling. Environ Chem Lett 1, 68-72.

Minnikin, D. E., Collins, M. D. \& Goodfellow, M. (1979). Fatty acid and polar lipid composition in the classification of Cellulomonas, Oerskovia and related taxa. J Appl Bacteriol 47, 87-95.
Minnikin, D. E., Hutchinson, I. G., Caldicott, A. B. \& Goodfellow, M. (1980). Thin-layer chromatography of methanolysates of mycolic acid-containing bacteria. J Chromatogr A 188, 221-233.

Minnikin, D. E., O’Donnell, A. G., Goodfellow, M., Alderson, G., Athalye, M., Schaal, A. \& Parlett, J. H. (1984). An integrated procedure for the extraction of bacterial isoprenoid quinones and polar lipids. J Microbiol Methods 2, 233-241.

Saitou, N. \& Nei, M. (1987). The neighbor-joining method: a new method for reconstructing phylogenetic trees. Mol Biol Evol 4, 406425.

Sasser, M. (1990). Identification of bacteria by gas chromatography of cellular fatty acids. USFCC Newsl 20, 16.

Shirling, E. D. \& Gottlieb, D. (1966). Methods for characterization of Streptomyces species. Int J Syst Bacteriol 16, 313-340.

Smibert, R. M. \& Krieg, N. R. (1994). Phenotypic characterization. In Methods for General and Molecular Bacteriology, pp. 607-654. Edited by P. Gerhardt, R. G. E. Murray, W. A. Wood \& N. R. Krieg. Washington, DC: American Society for Microbiology.

Stackebrandt, E. \& Goebel, B. M. (1994). Taxonomic note: a place for DNA-DNA reassociation and $16 S$ rRNA sequence analysis in the present species definition in bacteriology. Int J Syst Bacteriol 44, 846-849.

Staneck, J. L. \& Roberts, G. D. (1974). Simplified approach to identification of aerobic actinomycetes by thin layer chromatography. Appl Microbiol 28, 226-231.

Warhurst, A. M. \& Fewson, C. A. (1994). Biotransformations catalyzed by the genus Rhodococcus. Crit Rev Biotechnol 14, 29-73.

Xu, J. L., Gu, X. Y., Shen, B., Wang, Z. C., Wang, K. \& Li, S. P. (2006a). Isolation and characterization of a carbendazim-degrading Rhodococcus sp. djl-6. Curr Microbiol 53, 72-76.

Xu, J. L., Wang, Z. C., Wang, K. \& Li, S. P. (2006b). The isolation, identification and degradation characters of an efficient carbendazimdegrading bacterium. China Environ Sci 26, 307-310 (in Chinese).

Xu, J. L., He, J., Wang, Z. C., Wang, K., Li, W. J., Tang, S. K. \& Li, S. P. (2007). Rhodococcus qingshengii sp. nov., a carbendazim-degrading bacterium. Int J Syst Evol Microbiol 57, 2754-2757.

Yassin, A. F. (2005). Rhodococcus triatomae sp. nov., isolated from a blood-sucking bug. Int J Syst Evol Microbiol 55, 1575-1579.

Yoon, J. H., Cho, Y. G., Kang, S. S., Kim, S. B., Lee, S. T. \& Park, Y. H. (2000). Rhodococcus koreensis sp. nov., a 2,4-dinitrophenol-degrading bacterium. Int J Syst Evol Microbiol 50, 1193-1201.

Zhang, J., Zhang, Y., Xiao, C., Liu, Z. \& Goodfellow, M. (2002). Rhodococcus maanshanensis sp. nov., a novel actinomycete from soil. Int J Syst Evol Microbiol 52, 2121-2126.

Zhang, G. S., Jia, X. M., Cheng, T. F., Ma, X. H. \& Zhao, Y. H. (2005a). Isolation and characterization of a new carbendazim-degrading Ralstonia sp. strain. World J Microbiol Biotechnol 21, 265-269.

Zhang, Y. Q., Li, W. J., Kroppenstedt, R. M., Kim, C. J., Chen, G. Z., Park, D. J., Xu, L. H. \& Jiang, C. L. (2005b). Rhodococcus yunnanensis sp. nov., a mesophilic actinobacterium isolated from forest soil. Int $J$ Syst Evol Microbiol 55, 1133-1137.

Zopf, W. (1891). Über Ausscheidung von Fettfarbstoffen (Lipochromen) seitens gewisser Spaltpilze. Ber Dtsch Bot Ges 9, 2228 (in German). 